\title{
SPECC1/PDGFRB Fusion Protein
}

National Cancer Institute

\section{Source}

National Cancer Institute. SPECC1/PDGFRB Fusion Protein. NCI Thesaurus. Code C99834.

A fusion protein encoded by the SPECC1/PDGFRB fusion gene. This protein is comprised of almost the entire cytospin-B protein fused to the C-terminal transmembrane and cytoplasmic domains of the beta-type platelet-derived growth factor receptor protein, including the protein kinase domain. 